\title{
Theatre and Memory Wars Editorial
}

\section{EDGARAS KLIVIS \& RŪTA MAŽEIKIENĖ Vytautas Magnus university}

The issue of memory wars relates both to the political violence and armed conflicts of the past and conflicting memories of the violent historical experiences in contemporary societies. The confrontation between different and often opposite interpretations of history appears particularly relevant with the recent rise of the rhetoric of war (information war, new cold war, hybrid warfare, war on terrorism, etc.) often relating to (or rooted in) the prior historical conflicts and their popular or institutional memory in different states and social groups. Although notably linked to contemporary political and social realities of Baltic States and Eastern Europe, the issue of memory wars has a broad appeal as it can focus on the conflicting, inconsistent and agonistic nature of historical evaluations and memories.

World War II and the violence of the Holocaust, as well as post-war occupations, mass deportations and political persecutions crucially impacted the cultures of history and memory in different countries around the Baltic sea and still support deep divisions along social and ethnic lines and along the lines of regional and European identities. By pointing out the roles that we take in the memories of war (the roles of victims or that of oppressors) as well as the ways of dealing with contested memories, sharing dramatic histories and cultivating empathy, the issue of memory wars in theatrical practices is especially relevant. As the representations of memory and history, both conflicting and dialogic become increasingly important in theatre productions, this issue naturally infiltrates the field of theatre studies ${ }^{1}$.

1 For example, the issue of the performative means of reconstructing the past and the understanding of history as a shifting range of meanings produced by different cultural, social and political practices (such as rituals of public memory, historical re-enactments, museums, memorials etc.) have been addressed in the international conference "The Past Is Still to Change: Performing History from 1945 to the Present", organized at Vytautas Magnus university in 2009, in Kaunas, which also served as a basis for a special Volume of the journal Art History \& Criticism. http://menufakultetas.vdu.lt/wp-content/uploads/2016/10/MIK_6.pdf 
The issue of theatre and memory wars was addressed at the annual conference of the Association of Nordic Theatre Scholars, which was co-organized by the Department of Theatre Studies at Vytautas Magnus University and the Association of Nordic Theatre Scholars and was held at Vytautas Magnus University in Kaunas, Lithuania on $23-26$ April, 2018². With memory wars we offered to explore the performativity of memory, delving deeper into specific memories of conflicts and conflicting memories, contested pasts and agonistic historiographies. Rather than (or besides) asking how drama, theatre and performance function as instruments for shaping collective memories and identities, we suggested turning to how theatre can mediate between different, opposing and fragmented memories. Can theatrical memory machines (to use the term by Marvin Carlson ${ }^{3}$ ) be used in negotiating contested pasts and what are the advantages of theatre as a social instrument of memory among others (monuments, museums, pictures)? How can the theatrical public sphere contribute to "domesticating" antagonistic histories on national and international levels? How are theatre historiographies affected by historical conflicts as well as frameworks of the politics of memory and memory wars?

The topic of the conference attracted theatre researchers not only from the Nordic - Baltic region, but also from such countries as United Kingdom, United States of America, Ireland, Israel, the Netherlands, Germany, Austria and Russia. Thirty-five conference delegates together with key-note speakers (Freddie Rockem, Milija Gluhovic and Gintautas Mažeikis) focused on various theatre practices, revealing different artistic strategies of staging and representing war, personal and collective traumas, contested memories and conflicting testimonies of historical and contemporary events. Inspired by the questions raised at the conference we invited theatre researchers from different countries to explore the conflicting questions of memory wars in the articles in this special issue of Nordic Theatre Studies.

A number of articles in the issue address the question of how theatre works as a memory machine, especially with regard to memories of war or the Holocaust and how theatrical memory gets involved into wider circles of ideological confrontations related to the traumatic historical events. Annelis Kuhlmann offers a close reading of the performance "Memoria" (1990), directed by Eugenio Barba and performed by Else Marie Laukvik and Frans Winther, based on a book by Yaffa Eliach Hasidic Tales of the Holocaust. This article presents a detailed reconstruction of the complex relationship between the child-protagonists of the story, the actors who perform them and the writers Primo Levi and Jean Améry. It is to these writers, survivors of the holocaust who eventually committed suicide, to whom the performance refers, and is dedicated to. The author reveals how the stage signs and experiences function as a machine of traumatic memory where parts of theatrical apparatus and their interaction appear as dynamics of memory affected by historical trauma. So the relation between the said and the unsaid is read as "delanguaging of memory" and using corporeal presence is seen as a way to "invite in the musical-cultural body memory of the spectator". The article points out how

2 See the conference programme and participants here http://menufakultetas.vdu.lt/en/conference/ 3 See Marvin Carlson, The Haunted Stage: The Theatre as Memory Machine, Ann Arbor: The University of Michigan Press, 2003. 
memories of war and the Holocaust are turned into memory wars as experienced by the survivor, the conflicting contest of revenge and reconciliation for the place in memory landscape and how through theatre apparatus, the spectators are involved in a co-struggle with and within the memories.

Theatrical apparatus as memory machine is also an important part of contemporary museums and other sites of memory and history. Exploring theatricalization as a curatorial strategy in the exhibition in the Tirpitz Museum in Blavand presenting bunkers built in Denmark by Germans during the last years of WWII, Karen Vedel reflects on her own experiences as the visitor to the museum with reference to the memories of war passed down by her family within the theoretical context of new museology and theatrical turn. The researcher asks the important question "what happened to the war?" - pointing out how theatrical techniques, like the voices of actors, encourage intimate experience and thus not only downplay the conflicting memories of occupation but also prevent the critical reflection of the historical developments such as national socialism.

Ina Pukelytè in her article "Political Influence on Theatre Historiography: Jewish Memory Topics in Lithuania" suggests that political aspirations and agendas of a country play a crucial role in defining what type of memories the society would carry on and defend. Relating to the almost absent memory of the rich theatrical culture of the Jewish communities in the interwar period in Lithuania (she is the author of a book on Jewish theatre history herself) she refers to the public controversy around the books by Lithuanian writers Rūta Vanagaite and Marius Ivaškevičius, both of whom happen to be theatre producers, concerning the memory of the Holocaust in Lithuania in 1940s and the participation of Lithuanians as perpetrators of the massacres of Jews. She points out the confrontation between different types of memories in the Eastern European society and referring mostly to the theoretical framework of Aleida Assmann, defines the conflicting memories as "functional" and "stored".

A number of articles in this issue maintain the necessity for a certain degree of conflict, disagreement, antagonism and polemics in theatre and caution against peaceful consensus centred around frozen, unchanging and homogeneous memory discourse supported by the dominant ideologies and social groups. In recent years the struggle against the interference of the political elite in the cultures of memory and attempts to control interpretations of history through censorship and funding measures have taken place in Poland. Niklas Füllner in his article analysing Oliver Frljić's performance Klątwa in Warsaw as well as a public scandal around this production, demonstrates two different positions - that of the Prime Minister Beata Szydło and the official heroic Polish historiography and that of Frljić with his focus on "agonistic pluralism" (to use the term by Chantal Mouffe) and "logic of emancipation" (by Jacques Rancière) used in the thought provoking reading of Polish national classics.

Political tensions in the contemporary world involving information wars as part of new warfare strategies of the $21^{\text {st }}$ century also directly affect history and memory issues. Jurgita Staniškytè, researching contemporary Lithuanian theatre productions dealing with the past, claims that one of the effects of the toxic fictionalization of media on Lithuanian theatre artists is a turn towards an uncritical interest in "truthful" personal memories, leading away from the 
complex investigations of the politics of perception as well as ideological and the intrinsically antagonistic character of memory. Locating the different performances representing history in contemporary Lithuanian theatre in the scale between "positivist vision of an unchangeable past" and "documentary theatre" and critically pointing out their social implications, Staniškytè speaks up for the potential of (theatrical) memory for change, innovation, reconfiguration and intrinsic heterogeneity.

Three articles of this issue relate to theatre caught up in the grip of historical conflicts of the $20^{\text {th }}$ century thus calling for recollection on the part of the researcher in the form of a reading of theatre events through their complex entanglement in major military and political conflicts of the past. Astrid von Rosen's contribution, concerning the stage design for the performance based on the adaptation of a novel by Vilhelm Moberg from 1942, sets out to reveal how "multisensory performance ecologies" relate to "broader ideological orders of the world". The context of WWII supports certain interpretations of stage signs filling the production with hidden messages ("to evoke the worlding of a Swedish mood of resistance") not unlike the practices of political allegories so characteristic of Eastern European theatre of the Cold War period and puts it into a perspective of explorations of theatre functioning under foreign regimes, hostile political systems, occupation and colonization.

Janne Risum in her article "The Foreign-Policy Aspect of Mei Lanfang's Soviet Tour in 1935" gives a detailed account of the tour of Mei Lanfang, the Chinese male performer of female roles, to Moscow in 1935, pointing out again how artistic practices can and should be researched through the reconstruction of historical political contexts. Although Mei Lanfang's Soviet tour attracted wide international attention as an aesthetic event (and fostered heated debates about "traditional Chinese stage conventions"), the author argues that, seen from the "point of view of international politics at the time", the tour was even more important as an act of cultural diplomacy, which "helped break a deadlock in foreign relations between the Soviet Union and the Republic of China", and catalyzed the formation of a Sino-Soviet non-aggression pact.

Finally, Pentti Paavolainen in his article "Cultural Trauma of the Civil War of 1918 Staged and Commemorated in Finland" offers a consistent historical overview of the development of the theatrical commemoration of the civil war in Finland in 1918 (an event that had similar and related developments in other European countries) and the conflicting ideological positions that intervened and changed the historical representations throughout the $20^{\text {th }}$ century.

The proposed subject, the multiple perspectives introduced at the conference and selected articles of this issue of Nordic Theatre Studies point out that memory wars that have been explored so far mostly in the context of public monuments and commemorations ${ }^{4}$ can also work as a perspective in theatre research.

4 See for example Heiko Pääbo "War of Memories: Explaining 'Memorials War' in Estonia", Baltic Secutiry and Defence Review, 2008, vol. 10, pp. 5-28. Karsten Brüggemann and Andres Kasekamp, "The Politics of History and the 'War of Monuments' in Estonia“, Nationalities Papers, 2008, vol. 36, pp. 425-448. Maria Mälksoo, "Liminality and Contested Eiuropeanness: Conflicting Memory Politics in the Baltic Space“, Identity and Foreign Policy: Baltic-Russian Relations and 
Among different academic concepts, such as hauntology, collective memory or democracy of memories, memory wars is a perspective that opens up significant developments in modern and contemporary European theatre.

\section{REFERENCES}

Carlson, Marvin. 2003. The Haunted Stage: The Theatre as Memory Machine. Ann Arbor: The University of Michigan Press.

Mälksoo, Maria. 2009. "Liminality and Contested Europeanness: Conflicting Memory Politics in the Baltic Space". Identity and Foreign Policy: Baltic-Russian Relations and European Integration, eds. Eiki Berg and Piret Ehin, Ashgate, 65-84.

Pääbo, Heiko. 2008. "War of Memories: Explaining 'Memorials War' in Estonia". Baltic Secutiry and Defence Review, vol. 10, 5-28.

European Integration, ed. By Eiki Berg and Piret Ehin, Ashgate, 2009, pp. 65-84, etc. 